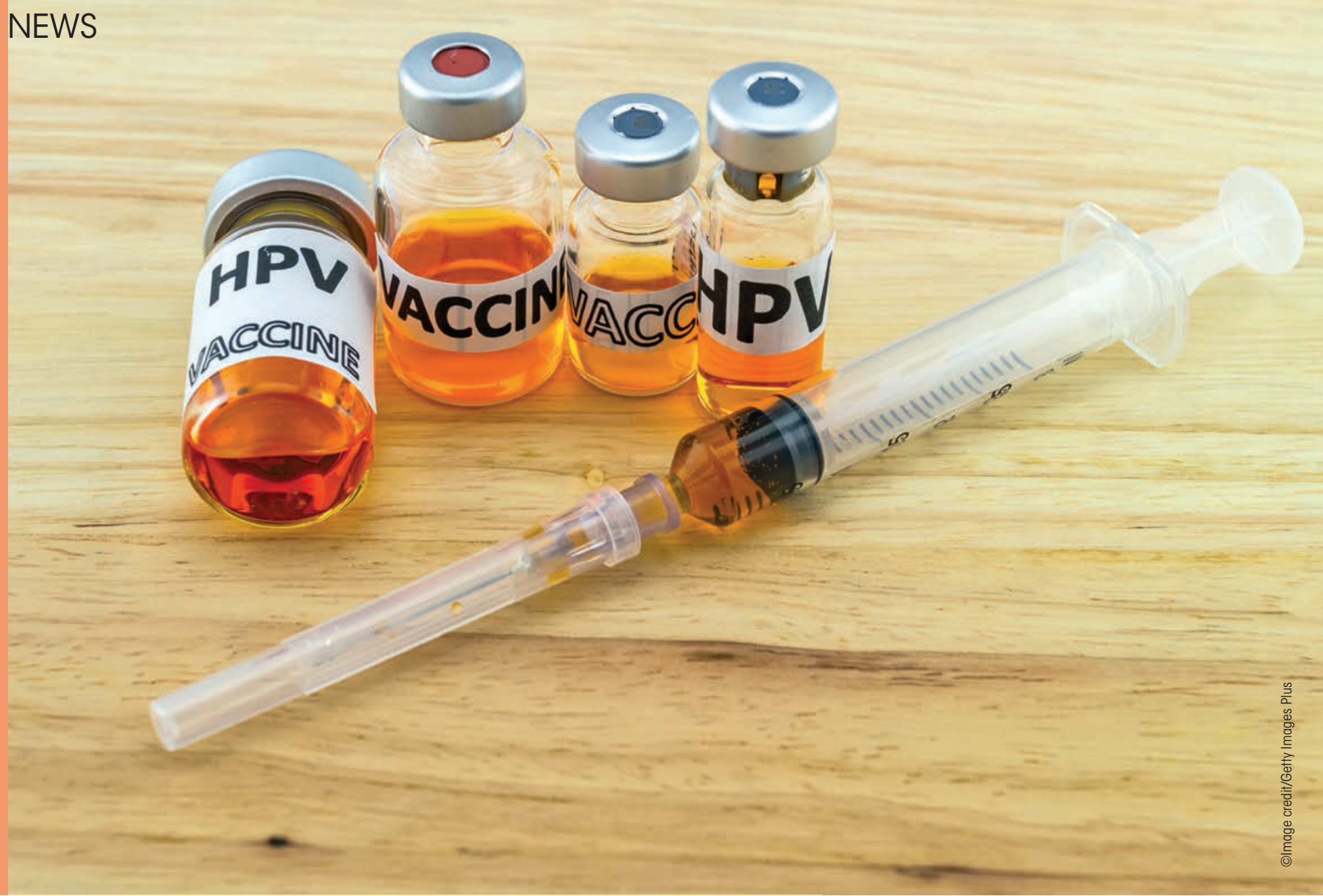

\title{
BADN BACKS CALL FOR GENDER NEUTRAL HPV VACCINATIONS
}

The British Association of Dental Nurses (BADN), the UK's only professional association specifically for dental nurses and the largest DCP association, has backed the call for gender-neutral HPV vaccinations, following a survey by the HPV Action Campaign showing support for the campaign from members of the Faculty of General Dental Practice and the British Dental Association. The survey was published during World Immunisation Week (24-28 April) and as the Government's vaccination advisory committee (JCVI) decides whether boys should also be given the HPV vaccination. An all-party open letter has been sent to Jeremy Hunt MP, the Health Secretary, urging him to ensure that the HPV vaccination programme is expanded to school age boys as well as girls.

Mick Horton, Dean of FGDP(UK) said 'The incidence of oral cancer has increased dramatically over the last decade, and over two-thirds of diagnoses are in men. HPV is a main causative agent, and the introduction of the NHS vaccination programme for girls has led to a significant reduction in the prevalence of the virus among women. Yet with over 2,000 men a year in the UK diagnosed with an HPV-related cancer - of whom almost half will die from the condition within five years - it is clear that current measures are not working for everyone. The view of oral health professionals is resounding - many of these lives could and should be saved by also vaccinating boys against HPV'.

HPV Action is asking members of the public, especially the parents of boys, to sign an online petition demanding gender-neutral vaccination: http://bit. ly/2nHaUul and will be calling on all political parties to commit themselves to gender-neutral HPV vaccination during the General Election campaign.

BADN President Jane Dalgarno said: 'Cancer prevention is, or should be, a gender-neutral issue. I am asking all dental nurses to sign the petition, and to write to their own MPs, urging them to support this campaign'.

\section{Dates for your diary: Jame}

\section{June 2017}

Periodontology for the dental team Location: Education Centre, Good Hope Hospital, Sutton Coldfield, 17:45 onwards Email: pthornley@btconnect.com

\section{June 2017}

Handling complaints and managing difficult patients Location: BDA, London, 10:00-16:30 www.bda.org

\section{June 2017}

Society of British Dental Nurses Annual Dental Nurse Symposium, 9:15-16:30 http://sbdn.org.uk/event/dentalsymposium-organised-s-b-d-n/

16 June 2017

An IRMER course in dental radiography and radiation protection, 10:00-17:00 Location: Crowne Plaza Manchester www.bda.org

\section{2-23 June 2017}

British Society of Periodontology Conference

Location: London

www.bsperio.org.uk/events 